\title{
Clinical spectrum of immunodeficiency, centromeric instability and facial dysmorphism (ICF syndrome)
}

\author{
M M Hagleitner, ${ }^{1}$ A Lankester, ${ }^{2}$ P Maraschio, ${ }^{3}$ M Hultén, ${ }^{4}$ J P Fryns, ${ }^{5}$ C Schuetz, ${ }^{6}$ \\ G Gimelli, ${ }^{7}$ E G Davies, ${ }^{8}$ A Gennery, ${ }^{9}$ B H Belohradsky, ${ }^{10} \mathrm{R}$ de Groot, ${ }^{1} \mathrm{E} J \mathrm{~A}$ Gerritsen, ${ }^{11}$ \\ T Mattina, ${ }^{12} \mathrm{P}$ J Howard, ${ }^{13} \mathrm{~A}$ Fasth, ${ }^{14}$ I Reisli, ${ }^{15}$ D Furthner, ${ }^{16} \mathrm{M}$ A Slatter, ${ }^{9} \mathrm{~A} J$ Cant, ${ }^{9}$ \\ $\mathrm{G}$ Cazzola, ${ }^{17} \mathrm{P} \mathrm{J}$ van Dijken, ${ }^{18} \mathrm{M}$ van Deuren, ${ }^{19} \mathrm{~J} \mathrm{C}$ de Greef, ${ }^{20} \mathrm{~S} \mathrm{M}$ van der Maarel, ${ }^{20}$ \\ C M R Weemaes ${ }^{1}$
}

See end of article for authors' affiliations

\section{Correspondence to:}

C M R Weemaes, Department of Pediatric Immunology, Radboud University Nijmegen Medical Centre, PO Box 9101, 6500 HB Nijmegen, The Netherlands; c.weemaes@cukz.umcn.nl

Received 24 July 2007 Revised 12 September 2007 Accepted 13 September 2007 Published Online First 24 September 2007
ABSTRACT

Background: Immunodeficiency, centromeric instability and facial dysmorphism (ICF syndrome) is a rare autosomal recessive disease characterised by facial dysmorphism, immunoglobulin deficiency and branching of chromosomes 1, 9 and 16 after PHA stimulation of lymphocytes. Hypomethylation of DNA of a small fraction of the genome is an unusual feature of ICF patients which is explained by mutations in the DNA methyltransferase gene DNMT3B in some, but not all, ICF patients.

Objective: To obtain a comprehensive description of the clinical features of this syndrome as well as genotypephenotype correlations in ICF patients.

Methods: Data on ICF patients were obtained by literature search and additional information by means of questionnaires to corresponding authors.

Results and conclusions: 45 patients all with proven centromeric instability were included in this study. Facial dysmorphism was found to be a common characteristic ( $n=41 / 42$ ), especially epicanthic folds, hypertelorism, flat nasal bridge and low set ears. Hypo- or agammaglobulinaemia was demonstrated in nearly all patients ( $n=39 / 44)$. Opportunistic infections were seen in several patients, pointing to a T cell dysfunction. Haematological malignancy was documented in two patients. Life expectancy of ICF patients is poor, especially those with severe infections in infancy or chronic gastrointestinal problems and failure to thrive. Early diagnosis of ICF is important since early introduction of immunoglobulin supplementation can improve the course of the disease. Allogeneic stem cell transplantation should be considered as a therapeutic option in patients with severe infections or failure to thrive. Only 19 of 34 patients showed mutations in DNMT3B, suggesting genetic heterogeneity. No genotype-phenotype correlation was found between patients with and without DNMT3B mutations.

In 1978 two patients were reported independently who shared specific facial characteristics, immunodeficiency and instability of pericentromeric regions of chromosomes 1,9 and 16 upon cytogenetic testing (ICF syndrome). ${ }^{1}{ }^{2}$ So far some 30 patients have been reported, ${ }^{3-28}$ most of them at very young age. In most patients reduced serum immunoglobulin levels as well as severe recurrent, and often fatal, infections were documented. Mild facial anomalies are a common characteristic of which epicanthic folds, hypertelorism and a flat nasal bridge are most frequently reported. Centromeric instability is the hallmark of the disease with ICF patients. In only a small percentage of the genome, most notably on the sat 2 and 3 repeats on chromosome 1, 9 and 16, DNA methylation is strongly reduced. ${ }^{29} 30$ Decondensation of these regions leads to the characteristic cytogenetic abnormalities which are prone to breakage and rejoining, leading to the formation of multiradiate chromosomes in mitogen-stimulated lymphocytes. ${ }^{15}$ In 1998 a locus associated with ICF syndrome was mapped to the proximal long arm of chromosome $20{ }^{31}$ This region contains a de novo DNA methyltransferase gene, DNMT3B, and mutations in this gene were identified in ICF patients. ${ }^{32}{ }^{33}$ However, mutations were not demonstrated in all patients investigated, suggesting involvement of other genes in ICF syndrome. ${ }^{34}$

The aim of the present study was to obtain a comprehensive description of the clinical features of ICF syndrome, the natural history as well as possible genotype-phenotype correlations in such patients.

\section{PATIENTS AND METHODS}

A computer assisted literature search using Pubmed and EMBASE was conducted to identify and obtain data on patients with ICF syndrome. Only patients showing the cytogenetic hallmark of the diagnosis-that is, instability of the pericentromeric heterochromatin of chromosomes 1, 9 and 16 upon PHA stimulation-were included in the study. Supplementary information was obtained from questionnaires completed by their attending physicians. Data of patients previously reported in the literature $(n=32)$ were updated and new patients $(n=13)$ have been included. Ethical approval was obtained for the publication of these data.

Questions focused on age at diagnosis, facial anomalies, psychomotor development, hypotonia and gastrointestinal problems. The diagnosis of immunodeficiency was made by reductions of serum IgG, IgG subclasses, IgA and/or IgM according to age standardised reference ranges. Agammaglobulinaemia was defined as a decrease of IgG below $2.5 \mathrm{~g} / \mathrm{l}$. Special attention was given to frequency and type of infections and laboratory results reflecting immunological status. These included complete blood count, level of serum immunoglobulins G, A, M, E and IgG subclasses 
and number of $\mathrm{T}$ and $\mathrm{B}$ lymphocyte subpopulations.

\section{RESULTS}

A total of 45 ICF patients were included in this study (table 1).

\section{Sociodemographic features}

The 45 patients include 25 males and 20 females, originating from 39 families, with consanguinity confirmed in 18 patients (table 1). There were six sibling pairs. In two children with a positive family history the diagnosis of ICF was confirmed shortly after birth through genetic analysis on cord blood (patient 16, 33).

Seventeen patients (40.5\%) died, with cause of death being predominantly severe respiratory tract infections, sepsis and failure to thrive. Median age at death was 8 years (range 6 months-42 years).

\section{Facial anomalies}

In most evaluable patients (41/42) typical distinctive facial appearances were found (fig 1, table 2). Hypertelorism, flat nasal bridge, epicanthic folds and low set ears were most frequent. The combination of epicanthic folds, hypertelorism, flat nasal bridge and low set ears was observed in 11 cases. Among those patients who were followed into adulthood only one had no facial anomalies (patient 25). Patient 30 had complaints of chronic fatigue at the age of 17 , due to a sleep/ apnoea syndrome caused by anatomic anomalies of the tongue.

\section{Congenital defects}

The most common malformations found were inguinal hernia and hypospadia (4/42), cleft palate (3/42) and syndactyly (2/ 42). Cardiac anomalies were reported in two patients and included a ventricular septal defect and an atrial septal defect (patients 31 and 39, respectively). Congenital hypothyroidism was found in one patient (patient 42).

Cerebral malformations were reported in individual patients and include focal cortical heterotopy, corpus callosum hypoplasia and hydrocephalus (patients 40, 8 and 5, respectively).

\section{Immunodeficiency and infections}

With the exception of one (patient 14), all remaining patients had documented signs of immunodeficiency (table 1). Patient 5 died at 6 months; follow up was too short in order to draw conclusions regarding the immune status. In 27 patients the immunoglobulin levels were consistent with a diagnosis agammaglobulinaemia; they all had B cells. Twelve patients had decreased levels of all immunoglobulins and four patients were reported with selective IgA (patient 2), IgM (patients 13 and 21) and IgG2 subclass deficiency (patient 19). The diagnosis of hypo/agammaglobulinaemia was made in early childhood in all patients (median age 3 years). Data for $T$ cell subpopulations were available for 38 patients (table 2). Normal percentages of $\mathrm{T}$ cells were observed in all but two patients (patients 5 and 9), and CD4 positive cells were decreased $(<\mathrm{p} 10)$ in five of 38 patients $(13.1 \%)$. A limited number of patients underwent $\mathrm{T}$ cell function testing in vitro. Of the 28 tested, three patients showed decreased or absent proliferation when stimulated with the mitogen PHA.

At the time of data collection, 29 patients were receiving intravenous immunoglobulin (IVIG) replacement.

Infections were a prominent clinical feature for 43 patients with available data (table 2 ) and were the leading cause of death (table 1) for 12 patients $(26.6 \%)$. The most common were respiratory tract infections in 35 patients (81.4\%). Three patients were reported with Pneumocystis jiroveci pneumonia (patients 11, 29 and 43). Sepsis was reported in 10 patients. In six patients, positive blood cultures were reported including Staphylococcus aureus (patients 3 and 13), Pseudomonas (patients 17 and 45) and Klebsiella species (patients 15 and 29). Streptococcus pneumoniae meningitis was documented in one patient (patient 39) and persistent Candida stomatitis in six (patients 5, 8, 9, 10, 44 and 45). Patient 13, with known selective IgM deficiency, developed a progressive multifocal leucoencephalopathy, due to JC virus ${ }^{14}$ at the age of 35 years; at that moment she had an agammaglobulinaemia. Infections with JC virus, Pneumocystis jiroveci and Candida suggest that a subtle defect of $\mathrm{T}$ cell function must be present, apart from the hypogammaglobulinaemia.

Gastrointestinal problems were reported in 27 patients $(65.8 \%)$ (table 2) and included multiple episodes of acute diarrhoea in 18 patients (43.9\%). Seven had chronic diarrhoea, two with persistent bacterial enteritis (salmonella in patient 6; campylobacter in patient 33). For three patients (patients 8, 15 and 29) diarrhoea was severe enough to warrant the administration of total parenteral nutrition for several months.

In four patients allogeneic stem cell transplantation (alloSCT) has been performed (patient 24 because of MDS; patients 33, 34 and 43 for infections and failure to thrive).

\section{Malignancies and haematological abnormalities}

Haematological malignancies were reported in two patients and included one patient who developed a classical Hodgkin lymphoma (patient 37), ${ }^{25}$ and a second patient who developed myelodysplastic syndrome (patient 24). Patient 45 developed aplastic anaemia. An adrenocortical adenoma was described in one patient (patient 39). Acquired leucopenia and thrombocytopenia of unknown origin were documented in patients 16, 30 and 41. In two of them (patients 16 and 41) cortical atrophy evolved at the same time without evidence of an infectious origin.

\section{Growth, development and neurological problems}

The average gestational age was 38 weeks (range 30-42 weeks). Eight patients (18.6\%) were born preterm. Among the 35 patients with adequate growth records, 20 (57.1\%) had a birth weight below the 10th centile (table 2) according to the World Health Organization Child Growth Standard. Data regarding sexual maturation were available in 10 cases: all entered puberty normally.

Developmental milestones were delayed in 28 of 41 patients (68.3\%). Of these, 18 (43.9\%) were delayed in speech development and $21(51.2 \%)$ did not start walking until 18 months of age. Nine patients with a delayed motor development were reported with hypotonia. Intelligence quotients were available from 44 patients, with $17(38.6 \%)$ showing a normal intelligence, $17(38.6 \%)$ a mild retardation and $10(22.7 \%)$ moderate retardation.

Five patients (patients 2, 12, 16, 18 and 41) had cortical atrophy. Two of them (patients 12 and 18) developed generalised tonic-clonic seizures within their first 2 years of life. Two other patients (patients 2 and 16) had a progressive deterioration of cognitive functions at the age of 10 years.

\section{Genetics}

A total of 35 individuals with the syndrome were screened for mutations of the gene DNMT3B (table 1). Mutations were 


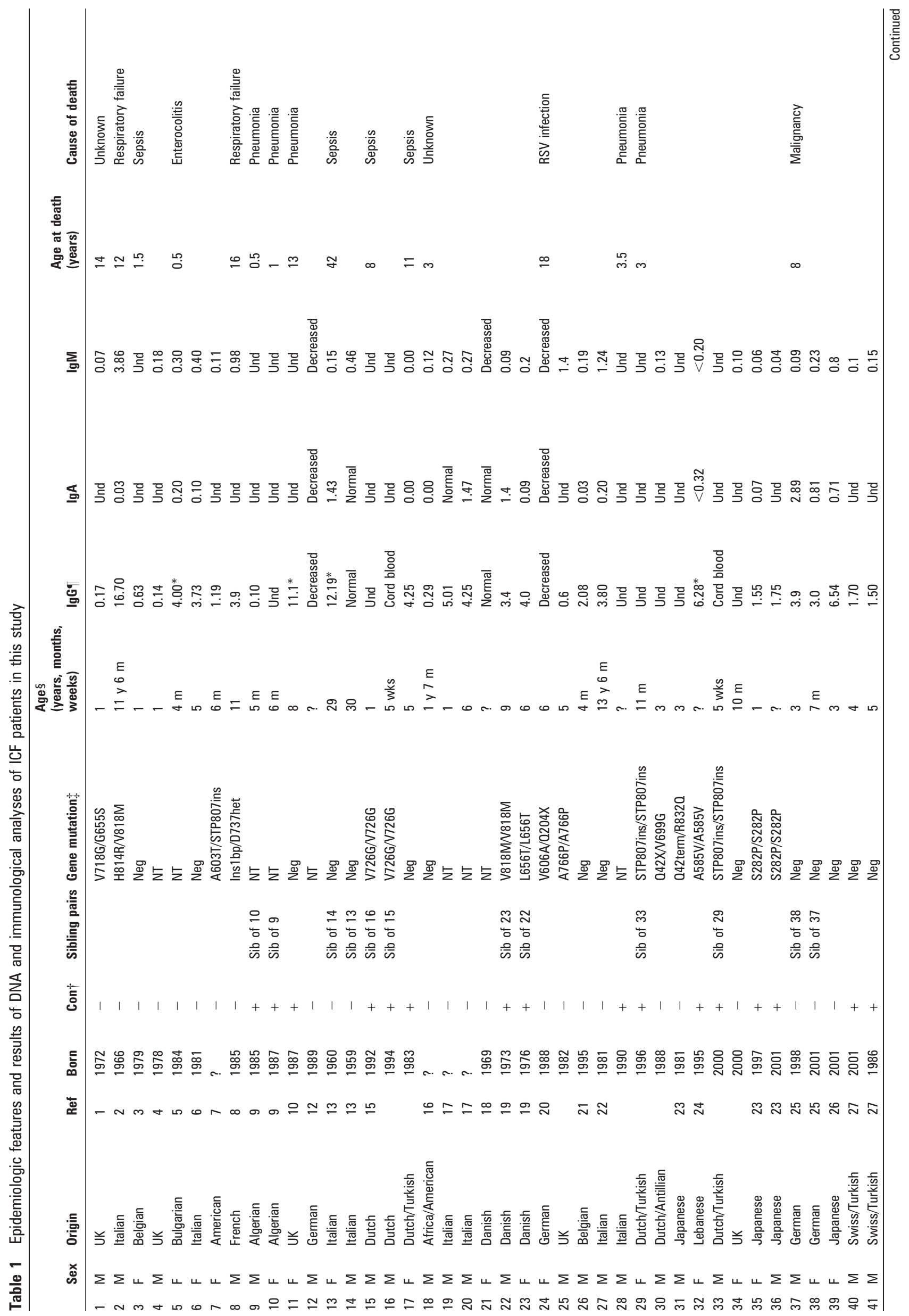




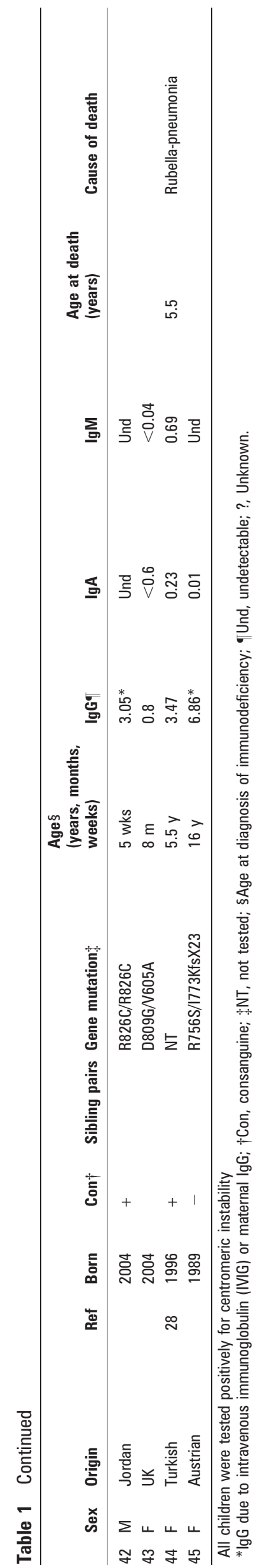

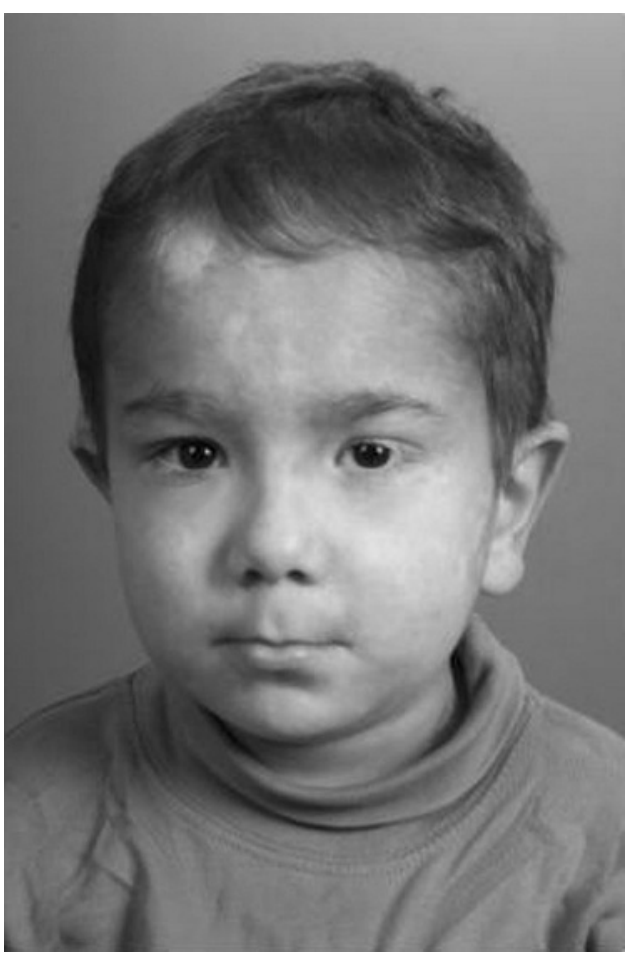

Figure 1 Patient with typical ICF features: hypertelorism, epicanthic folds, flat nasal bridge and up turned nose. Parental/guardian informed consent was obtained for publication of this figure.

detected in $20(57.1 \%)$ cases. Ten patients showed a homozygous mutation, the remainder were compound heterozygous. The homozygous patients were all of proven consanguineous descent. One patient (patient 25) born from non-consanguineous parents had a single mutation. The majority of mutations are missense mutations (table 1). Other mutations included nonsense mutations and splice-site mutations.

In order to study a possible genotype-phenotype correlation the cases in this report were divided into two groups based on mutation data. Group 1 entailed those with DNMT3B mutation $(\mathrm{n}=20)$, and group 2 included those without mutation after DNA analysis $(n=15)$. As shown in table 2 , no relevant differences were noted concerning immunology, facial findings and development. The number and severity of infections was similar in both groups.

\section{DISCUSSION}

The diagnosis of ICF is based on the triad of immunodeficiency, centromeric region instability and facial dysmorphism. ${ }^{12}$ The clinical spectrum in this study group, however, was very broad. In this study of cytogenetically proven ICF patients it became clear that these hallmarks are not equally present in all patients. While centromeric region instability was by definition present in all patients, facial dysmorphism was lacking in some and the immune defect varied from a severe combined immunodeficiency to nearly normal immunity.

In most patients facial dysmorphism was present and included hypertelorism, flat nasal bridge, epicanthic folds, low set ears, micrognathia or upturned nose. One patient developed a nocturnal sleep apnoea syndrome due to abnormalities of the tongue and motor problems of the mouth (patient 30). Obvious facial dysmorphism at birth without other symptoms at that time was the reason for cytogenetic studies in one patient (patient 42), leading to the diagnosis of ICF syndrome. Another patient (patient 25) did not have dysmorphism at all, while 
Table 2 Clinical data and results of immunological analyses in relation to presence or absence of DNMT3B mutation

\begin{tabular}{|c|c|c|c|}
\hline & Total* & $\begin{array}{l}\text { DNMT3B } \\
\text { mutation }\end{array}$ & No mutation \\
\hline Demographic features & Total 45 & Total $20 \dagger$ & Total $15 \dagger$ \\
\hline Consanguine & $18 / 45$ & $10 / 20$ & $4 / 15$ \\
\hline Died & $17 / 42$ & $5 / 18$ & $3 / 15$ \\
\hline \multicolumn{4}{|l|}{ Growth and development } \\
\hline Gestational age $<37$ weeks & $8 / 43$ & $2 / 18$ & $4 / 15$ \\
\hline Birth weight $\leqslant \mathrm{p} 10$ & $20 / 35$ & $6 / 17$ & $6 / 8$ \\
\hline Failure to thrive & $21 / 41$ & $6 / 16$ & $8 / 15$ \\
\hline Delays in motor development & $21 / 41$ & $10 / 17$ & $9 / 15$ \\
\hline $\begin{array}{l}\text { Delays in speech and language development } \\
\text { Intelligence }\end{array}$ & $18 / 41$ & $7 / 14$ & $7 / 15$ \\
\hline Normal intelligence & $17 / 44$ & $11 / 20$ & $4 / 15$ \\
\hline Mild retardation & $17 / 44$ & $4 / 20$ & $8 / 15$ \\
\hline Moderate retardation & $10 / 44$ & $5 / 20$ & $3 / 15$ \\
\hline \multicolumn{4}{|l|}{ Craniofacial features } \\
\hline Hypertelorism & $27 / 42$ & $10 / 18$ & $10 / 15$ \\
\hline Flat nasal bridge & $25 / 42$ & $13 / 18$ & $9 / 15$ \\
\hline Epicanthus & $25 / 42$ & $13 / 18$ & $7 / 15$ \\
\hline Low set ears & $20 / 42$ & $8 / 18$ & $7 / 15$ \\
\hline Micrognathia & $12 / 42$ & $5 / 18$ & $4 / 15$ \\
\hline Up-turned nose & $14 / 42$ & $6 / 18$ & $6 / 15$ \\
\hline Round face & $11 / 42$ & $7 / 18$ & $3 / 15$ \\
\hline Macroglossia & $8 / 42$ & $4 / 18$ & $3 / 15$ \\
\hline Telecanthus & $9 / 42$ & $4 / 18$ & $2 / 15$ \\
\hline High forehead & $10 / 42$ & $3 / 18$ & $3 / 15$ \\
\hline Tongue protrusion & $7 / 42$ & $2 / 18$ & $3 / 15$ \\
\hline Congenital malformation & $17 / 42$ & $3 / 18$ & $4 / 15$ \\
\hline \multicolumn{4}{|l|}{ Gastrointestinal problems } \\
\hline Diarrhoea & $18 / 41$ & $7 / 16$ & $6 / 15$ \\
\hline Malabsorption & $4 / 41$ & $2 / 16$ & $1 / 15$ \\
\hline \multicolumn{4}{|l|}{ Infections } \\
\hline Bronchopneumonia & $35 / 43$ & $15 / 18$ & $11 / 15$ \\
\hline Otitis & $13 / 43$ & $8 / 18$ & $3 / 15$ \\
\hline Sepsis & $8 / 43$ & $2 / 18$ & $6 / 15$ \\
\hline Candida infection & $6 / 33$ & $2 / 18$ & $0 / 15$ \\
\hline Pneumocystis jerovici & $3 / 33$ & $2 / 18$ & $1 / 15$ \\
\hline \multicolumn{4}{|l|}{ Neurology } \\
\hline Cerebral atrophy & $5 / 45$ & $2 / 20$ & $2 / 15$ \\
\hline Seizures & $3 / 45$ & $0 / 20$ & $2 / 15$ \\
\hline \multicolumn{4}{|l|}{ Immunology } \\
\hline Agammaglobulinaemia & $26 / 45$ & $14 / 20$ & $8 / 15$ \\
\hline Hypogammaglobulinaemia & $12 / 45$ & $5 / 20$ & $4 / 15$ \\
\hline IgM deficiency & $2 / 45$ & $0 / 20$ & $1 / 15$ \\
\hline $\lg \mathrm{A}$ deficiency & $1 / 45$ & $1 / 20$ & $0 / 15$ \\
\hline IgG2 subclass deficiency & $1 / 45$ & $0 / 20$ & $0 / 15$ \\
\hline \multicolumn{4}{|l|}{$\mathrm{T}$ cells } \\
\hline CD 4 decreased & $7 / 38$ & $2 / 17$ & $2 / 15$ \\
\hline
\end{tabular}

${ }^{*}$ All cytogenetically proven ICF patients.

$\uparrow 10$ patients who were not screened for DNMT3B mutation are not listed.

patient 16 had normal features at birth and developed dysmorphism during childhood. Therefore, absent dysmorphism in patients with agammaglobulinaemia, in whom B cells are present, does not preclude ICF syndrome and cytogenetic analysis should be considered. In addition a variety of congenital malformations were seen suggesting that DNMT3B plays an important broad role during embryogenesis. Further evidence for the role of $D N M T 3 B$ in embryogenesis/morphogenesis was recently provided in transgenic mice models. ${ }^{35}$

The most prominent clinical feature in the study group was respiratory tract infections, with at least one episode of bronchopneumonia occurring in nearly all of the cases. Severe pulmonary infections were also the most common cause of death, indicative of the severity of immunodeficiency in these patients. By an unknown mechanism it is possible that DNMT3B mutations-probably as a result of DNA hypomethylation-are involved in lymphogenesis dysregulation causing this immunodeficiency. ${ }^{36}$

Two patients with a positive family history of ICF were treated from birth with IVIG and did not have pulmonary infections in infancy. This has also been described in patients with X-linked agammaglobulinaemia (XLA), who are now surviving into adulthood with fewer pulmonary problems due to earlier treatment with IVIG. ${ }^{37}$

Normally, infections in patients with agammaglobulinaemia are mostly caused by pyogenic encapsulated bacteria such as Streptococcus pneumoniae or Haemophilus influenzae. These microorganisms were observed in only a minority of the ICF patients. Opportunistic infections such as Pneumocystis jiroveci or severe candida stomatitis occurred in several ICF patients with apparently only a B cell defect and normal T cell numbers and function.

This suggests that a subtle defect of $\mathrm{T}$ cell function or a defect in antigen presenting cells (dendritic cells or monocytes) must be present. Studies in murine ICF models have demonstrated an effect on postnatal thymocyte survival. ${ }^{35}$ Further studies are required to determine the impact on peripheral $\mathrm{T}$ cell populations and their function in these mice and ICF patients. In practical terms this means that prophylaxis with co-trimoxazole should be employed.

A high proportion of the children died at a young age from respiratory infections or failure to thrive. In particular, children with gastrointestinal problems in combination with failure to thrive had a poor prognosis, leading to a worsening of the disease. Because the prognosis is poor in the patients with severe infections or failure to thrive, alloSCT should be considered in those patients. Recent experience indicates that alloSCT can be safely performed in ICF patients with improvement in immune function and clinical outcome. ${ }^{38}$

This study shows that growth retardation is a frequent problem in ICF patients. It is possible that initial growth problems were related to low birth weight. Furthermore, a number of children (43.9\%) suffered diarrhoea secondary to infections or other gastrointestinal problems, and half the children failed to thrive (51.2\%). In the case of two brothers with ICF, the elder with intestinal problems had poor growth, but his younger brother who was treated from birth with immunoglobulin substitution did not suffer from chronic diarrhoea, and had normal growth. This suggests that the poor growth is not directly related to the genetic defect.

One of the first reported patients with ICF suffered from severe mental retardation. ${ }^{2}$ We here demonstrate that, although the majority of children with ICF syndrome do have some degree of mental retardation $(27 / 44,61 \%)$, more than one third (16/41, 39\%) have normal intelligence. One child was reported as doing exceptionally well in high school showing that the disorder can exist without retardation. Children with ICF in this cohort frequently have difficulty with speech and gross motor skills. Physiotherapeutic support and speech therapy often has positive influence on their development. Neurological problems may develop over time. In three ICF patients (patients 2, 16 and 41) non-infectious encephalopathy was seen. Progressive deterioration and/or thrombocytopenia and leucopenia in combination with cerebral atrophy is similar to the pathology of neurological manifestations in systemic lupus erythematosus which is linked to DNA hypomethylation. ${ }^{39}$ Development of haematological abnormalities-for example, aplastic anaemia in patient 45, or thrombocytopenia and 
leucocytopenia seen in patient 30, who also developed hepatosplenomegaly and gonarthritis-may be caused by autoimmune mechanisms. Autoimmunity in the absence of antibodies suggests activation of autoreactive $T$ cells by $T$ cell receptor or innate activating receptors directly.

A predisposition to cancer is frequently associated with immunodeficiency. Various types of cancer such as breast adenocarcinomas, ${ }^{40}$ ovarian epithelial carcinomas ${ }^{41}$ and Wilms tumours $^{42}$ share with ICF syndrome cells the characteristic of hypomethylated satellite $2 \mathrm{DNA}$. It has been proposed that hypomethylation of this area affects chromatin structure leading to chromosomal instability as well as possibly altered gene expression. ${ }^{43}$ It is unclear whether the malignancy seen in patients 24 and 37 was a chance association or linked to the ICF syndrome.

Only 20 of the 35 patients tested showed mutations in $D N M T 3 B$, suggesting genetic heterogeneity. No genotypephenotype correlation was found. Thus patients with mutations in the DNMT3B gene have the same phenotype as patients without this mutation (table 2). In those with a demonstrable mutation, the phenotype differed widely. Two factors influenced our ability to demonstrate a genotype-phenotype correlation in this study: (1) the number of proven ICF patients was small; and (2) most patients were compound heterozygotes and most mutations occurred only once. ${ }^{34}$ It is likely that a complex interaction of factors leads to the broad variation in phenotypic characteristics as seen in ICF syndrome.

In conclusion, ICF syndrome should be considered in all patients with agammaglobulinaemia with $\mathrm{B}$ cells or common variable immunodeficiency, where other features such as a history of delayed milestones raise the possibility of ICF. Early diagnosis is important since early treatment with IVIG can improve the natural history of the disease. AlloSCT should be considered as a therapeutic option in patients with severe infections or failure to thrive.

This review of the spectrum of ICF features should contribute to a better recognition of ICF patients. Close follow up and central registration of patients will allow the prevalence and the natural history of the syndrome to become clearer.

Authors' affiliations: 'Department of Paediatric Immunology, Radboud University
Nijmegen Medical Centre, The Netherlands; ' 2 Department of Paediatrics, Leiden
University Medical Centre, The Netherlands; ' ${ }^{3}$ Dipartimento di Patologia Umana ed
Ereditaria, Biologica Generale e Genetica Medica, Università di Pavia, Italy;
${ }^{4}$ Department of Biological Sciences, University of Warwick, Coventry, UK; ${ }^{5}$ Centre of
Human Genetics, University Hospital Gasthuisberg, Leuven, Belgium; ${ }^{6}$ University
Hospital Ulm, Paediatrics, Germany; ' Laboratorio di Citogenetia, Instituto G Galini,
Genova, Italy; ${ }^{8}$ Department of Immunology, Great Ormond Street Hospital, London, UK;
${ }^{9}$ Paediatric Immunology Department, Newcastle General Hospital, Newcastle, UK;
${ }^{10}$ Department of Infectious Diseases and Immunology, University Children's Hospital
Munich, Germany; ${ }^{11}$ Department of Paediatrics, Oosterschelde Hospital, Goes, The
Netherlands; ${ }^{12}$ Dipartimento di Pediatrica, Genetica Medica University of Catania, Italy;
${ }^{13}$ Merseyside \& Cheshire Regional Genetics Laboratory Liverpool Women's Hospital,
Liverpool, UK; ${ }^{14}$ Department of Paediatrics, The Sahlgrenska Academy Göteborg,
Sweden; ${ }^{15}$ Department of Pediatric Immunology and Allergy, Selcuk University, Turkey;
${ }^{16}$ Landestrauen- \& Kinderklinik Linz, Austria; ${ }^{77}$ Centro Fibrosi Cistica, Verona, Italy;
${ }^{18}$ Department of Paediatrics, Elisabeth Hospital Tilburg, The Netherlands; ${ }^{19}$ Department
of Internal Medicine, Radboud University Nijmegen Medical Centre, The Netherlands;
${ }^{20}$ Department of Human Genetics, Leiden University Medical Centre, The Netherlands

Competing interests: None declared.

Ethics approval: Ethical approval was obtained for the publication of the data in this study.

Parental/guardian informed consent was obtained for publication of fig 1 .

\section{REFERENCES}

1. Hultén M. Selective somatic pairing and fragility at $1 q 12$ in a boy with common variable immunodeficiency: a new syndrome. Clin Genet 1978;14:294-5.
2. Tiepolo L, Maraschio P, Gimelli G, Cuoco C, Gargani GF, Romano C. Multibranched chromosomes 1, 9 and 16 in a patient with $\lg A$ and $\lg E$ deficiency. Hum Genet 1979;51:127-37.

3. Fryns JP, Azou M, Jaeken J, Eggermont E, Pederson JC, Van den Berge H. Centromeric instability of chromosome 1,9 and 16 associated with combined immunodeficiency. Hum Genet 1981;57:108-10.

4. Howard PJ, Lewis IJ, Harris F, Walker S. Centromeric instability of chromosomes 1 and 16 with variable immunodeficiency: a new syndrome. Clin Genet 1985;27:501-5.

5. Valkova G, Ghenev E, Tzancheva M. Centromeric instability of chromosomes 1, 9 and 16 with variable immunodeficiency. Support of a new syndrome. Clin Genet 1987;31:119-24.

6. Maraschio P, Zuffardi O, Dalla Fior P, Tiepolo L. Immunodeficiency, centromeric heterochromatin instability of chromosomes 1,9 and 16 and facial anomalies: the ICF syndrome. J Med Genet 1988;25:173-80.

7. Carpenter NJ, Filipovich A, Blease RM, Carey TL, Berkel Al. Variable immunodeficiency with abnormal condensation of the heterochromatin of chromosomes 1, 9 and 16. J Pediat 1988;112:757-60.

8. Turleau C, Cabanis MO, Girault D, Ledeist F, Mettey R, Puissant H, Prieur M de, Grouchy J. Multibranched chromosomes in the ICF syndrome: immunodeficiency, centromeric instability and facial anomalies. Am J Med Genet 1989;32:420-4.

9. Fasth A, Forestier E, Holmberg E, Holmgren G, Nordenson I, Söderström T, Wahlström J. Fragility of the centromeric region of chromosome associated with combined immunodeficiency in siblings. A recessively inherited entity? Acta Paediatr Scand 1990;79:605-12.

10. Bauld R, Grace E, Richards N, Ellis PM. The ICF syndrome: a rare chromosome instability syndrome. J Med Genet 1991;28:63a.

11. Brown D, Grace E, Sumner AT, Edmunds AT, Ellis PM. ICF syndrome (immunodeficiency, centromeric instability and facial anomalies): investigation of heterochromatin abnormalities and review of clinical outcome. Hum Genet 1995;96:411-16.

12. Kieback P, Wendisch H, Lorenz P, Hinkel K. ICF syndrome: Immundefizienz, chromosomale Zentromerinstabilität, faziale Anomalien; Fallvorstellung und Literaturübersicht, Monatsschr. Kinderheilkd 1992;140:91-4.

13. Gimelli G, Varone P, Pezzolo A, Lerone M, Pistoia V. ICF syndrome with variable expression in sibs. J Med Genet 1993;30:429-32.

14. Colucci M, Cocito L, Capello E, et al. Progressive multifocal leukoencephalopathy in an adult patient with ICF syndrome. J Neur Scie 2004;217:107-10.

15. Smeets D, Moog U, Weemaes C, Waes-Peeters G, Merks G, Niehof JP, Hamers G. ICF syndrome: a new case and review of the literature. Hum Genet 1994:94:240-6.

16. Sawyer JR, Swanson ChM, Wheeler G, Cunniff Ch. Chromosome instability in ICF syndrome: formation of micronuclei from multibranched chromosomes 1 demonstrated by fluorescence in situ hybridization. Am J Med Genet 1995;56:203-9.

17. Franceschini $\mathbf{P}$, Marino S, Ciochini M, Ciuti E, Vardeu MP, Guala A, Signorile F, Camerano P, Franceschini D, Tovo PA. Variability of clinical and immunological phenotype in immunodeficiency-centromeric instability-facial anomalies syndrome. Report of two new cases and review of the literature. Eur J Pediat 1995;154: 840-6.

18. Ostergard PA. A girl with recurrent infections, low IgM and an abnormal chromosome 1. Acta Paediat Scand 1973:62:211-15.

19. Tauris $\mathbf{P}$, Hansen $\mathbf{P}$. Functional studies on lymphocytes from two siblings with congenital hypogammaglobulinaemia. Scand J Haemotol 1983;30:117-24.

20. Schuffenhauer S, Bartsch 0, Stumm M, et al. DNA, FISH and complementation studies in ICF syndrome: DNA hypomethylation of repetitive and single coy loci and evidence for a trans acting factor. Hum Genet 1995;96:562-71.

21. De Ravel TJ, Deckers E, Alliet BL, Petit P, Fryns JP. The ICF syndrome: new case and update. Genet Couns 2001;12:379-85.

22. Pezzolo A, Prigione I, Chiesa S, Castellano E, Gimelli G, Pistoia V. A novel case of immunodeficiency, centromeric instability, and facial anomalies (the ICF syndrome): immunologic and cytogenetic studies. Haematol 2002;87:329-31.

23. Shirohzu H, Kubota T, Kumazawa A, Sado T, Chijiwa T, Inagaki K, Suetake I, Tajima S, Wakui K, Miki Y, Hayashi M, Fukushima Y, Sasaki H. Three novel DNMT3B mutations in Japanese patients with ICF syndrome. Am J Med Genet 2002;112:317.

24. Björck EJ, Bui T-H, Wijmenga C, Grandell U, Nordenskjöld M. Early prenatal diagnosis of the ICF syndrome. Prenat Diagn 2000;20:828-31.

25. Schuetz C, Barbi G, Barth TFE, Hoenig M, Schulz A, Möeller P, Smeets D, de Greef JC, van der Maarel SM, Vogel W, Debatin K-M, Friedrich W. ICF syndrome: high variability of the chromosomal phenotype in association with a classical Hodgkin Lymphoma. Am J Med Genet 2007;143:2052-7.

26. Kubota T, Furuumi H, Kamoda T, Iwasaki N, Tobita N, Fujiwara N, GotoY, Matsui A, Sasaki H, Kajii T. ICF syndrome in a girl with DNA hypomethylation but without detectable DNMT3B mutation. Am J Med Genet 2004;129A:290-3.

27. Kloeckener-Gruissem B, Betts DR, Zankl A, Berger W, Güngör T. A new and a reclassified ICF patient without mutations in DNMT3B and its interacting proteins SUMO-1 and UBC9. Am J Med Genet 2005;136A:31-7.

28. Reisli I, Yildirim MS, Koksal Y, Avunduk MC, Acar A. A case with ICF-syndrome lost to rubella pneumonitis. Turk J Pediatr 2005;47: 85-8.

29. Kondo T, Bobek MP, Kuick R, Lamb B, Zhu X, Narayan A, Bourc'his D, ViegasPéquignot $E$, Ehrlich M, Hanash SM. Whole-genome methylation scan in ICF syndrome: hypomethylation of non-satellite DNA repeats D4Z4 and NBL2. Hum Mol Genet 2000;9:597-604.

30. Jeanpierre M, Turleau C, Aurias A, Prieur M, Ledeist F, Fischer A, Viegas-Pequignot E. An embryonic-like methylation pattern of classical satellite DNA is observed in ICF syndrome. Hum Mol Genet 1993;2:731-5. 
31. Wijmenga C, van den Heuvel LP, Strengman E, Luyten JA, van der Burgt IJ, de Groot R, Smeets DF, Draaisma JM, van Dongen JJ, De Abreu RA, Pearson PL, Sandkuijl LA, Weemaes CM. Localization of the ICF syndrome to chromosome 20 by homozygosity mapping. Am J Hum Genet 1998;63:803-9.

32. Hansen RS, Wijmenga C, Luo P, Stanek AM, Canfield TK, Weemaes CMR, Gartler SM. The DNMT3B DNA methyltransferase gene is mutated in the ICF immunodeficiency syndrome. Proc Natl Acad Sci 1999;96:14412-7.

33. Xu GL, Bestor TH, Bourc'his D, Hsieh CL, Tommerup N, Bugge M, Hulten M, Ou X, Russo $\mathrm{JJ}$, Viegas-Pequignot E. Chromosome instability and immunodeficiency syndrome caused by mutations in a DNA methyltransferase gene. Nature 1999;402:187-91.

34. Wijmenga C, Hansen RS, Gimelli G, Björck EJ, Davies EG, Valentine D, Belohradsky $B$ H, van Dongen JJ, Smeets DF, van den Heuvel LP, Luyten JA, Strengman E, Weemaes C, Pearson PL. Genetic variation in ICF syndrome: evidence for genetic heterogeneity. Hum Mutat 2000;16:509-17.

35. Ueda Y, Okano M, Williams C, Chen T, Georgopoulos K, Li N. Roles for Dnmt3b in mammalian development: a mouse model for the ICF syndrome. Development 2006:133:1183-92.

36. Ehrlich M, Buchanan KL, Tsien F, Jiang G, Sun B, Uicker W, Weemaes CMR, Smeets D, Sperling K, Belohradsky BH, Tommerup N, Misek DE, Rouillard J-M, Kuick R, Hanash SM. DNA methyltransferase 3B mutations linked to the ICF syndrome cause dysregulation of lymphogenesis genes. Hum Mol Genet 2001:10:2917-31.
37. Howard V, Greene JM, Pahwa S, Winkelstein JA, Boyle JM, Kocak M, Conley ME. The health status and quality of life of adults with X-linked agammaglobulinemia. Clin Immunol 2006;118:201-8.

38. Gennery AR, Slatter MA, Bredius R, Hagleitner MM, Weemaes C, Cant AJ, Lankester AC. Hematopoeitic stem cell transplantation corrects the immunological abnormalities associated immunodeficiency, centromeric instability, facial dysmorphism syndrome. Pediatrics 2007;120:e1341-4.

39. Sekigawa I, Kawasaki M, Ogasawara $H$, et al. DNA methylation: its contribution to systemic lupus erythematosus. Clin Exp Med 2006;6:99-106.

40. Tsuda H, Takarabe T, Kanai Y, Fukutomi T, Hirohashi S. Correlation of DNA hypomethylation at pericentromeric heterochromatin regions of chromosomes 16 and 1 with histological features and chromosomal abnormalities of human breast carcinomas. Am J Path 2002;161:859-66.

41. Widschwendter M, Jiang G, Woods C, Müller HM, Fiegl H, Goebel G, Marth C, Müller-Holzner E, Zeimet AG, Laird PW, Ehrlich M. DNA hypomethylation and ovarian cancer biology. Cancer Res 2004;64:4472-80.

42. Ehrlich M, Hopkins NE, Jiang G, Dome JS, Yu MC, Woods CB, Tomlinson GE, Chintagumpala M, Champagne M, Dillerg L, Parham DM, Sawyer J. Satellite DNA hypomethylation in karyotyped Wilms tumors. Cancer Genet Cytogenet 2003;141:97105.

43. Ehrlich M. DNA methylation in cancer: too much, but also too little. Oncogene 2002;21:5400-13.

\section{Save your favourite articles and useful searches}

Use the "My folders" feature to save and organise articles you want to return to quickly-saving space on your hard drive. You can also save searches, which will save you time. You will only need to register once for this service, which can be used for this journal or all BMJ Journals, including the BMJ. 


\title{
Clinical spectrum of immunodeficiency, centromeric instability and facial dysmorphism (ICF syndrome)
}

\author{
M M Hagleitner, A Lankester, P Maraschio, et al. \\ J Med Genet 2008 45: 93-99 originally published online September 24, \\ 2007 \\ doi: 10.1136/jmg.2007.053397
}

Updated information and services can be found at:

http://jmg.bmj.com/content/45/2/93.full.html

\begin{tabular}{|c|c|}
\hline & These include: \\
\hline References & $\begin{array}{l}\text { This article cites } 43 \text { articles, } 9 \text { of which can be accessed free at: } \\
\text { http://jmg.bmj.com/content/45/2/93.full.htm|\#ref-list-1 }\end{array}$ \\
\hline & $\begin{array}{l}\text { Article cited in: } \\
\text { http://jmg.bmj.com/content/45/2/93.full.html\#related-urls }\end{array}$ \\
\hline $\begin{array}{l}\text { Email alerting } \\
\text { service }\end{array}$ & $\begin{array}{l}\text { Receive free email alerts when new articles cite this article. Sign up in } \\
\text { the box at the top right corner of the online article. }\end{array}$ \\
\hline $\begin{array}{r}\text { Topic } \\
\text { Collections }\end{array}$ & $\begin{array}{l}\text { Articles on similar topics can be found in the following collections } \\
\text { Immunology (including allergy) ( } 515 \text { articles) } \\
\text { Calcium and bone ( } 279 \text { articles) }\end{array}$ \\
\hline
\end{tabular}

Notes

To request permissions go to:

http://group.bmj.com/group/rights-licensing/permissions

To order reprints go to:

http://journals.bmj.com/cgi/reprintform

To subscribe to BMJ go to:

http://group.bmj.com/subscribe/ 